\title{
Taxation Practices and the Survival of Small and Medium-Sized Enterprises (SMEs)
}

\author{
Nnam Imaobong Judith, Amara Felix Maduabuchi, Ekete Linus Igwe, Okeke Stella Ehis, \\ Chukwunwike Onyekachi David*
}

Department of Accountancy, University of Nigeria, Enugu Campus, Nigeria

Received October 18, 2021; Revised January 14, 2022; Accepted February 8, 2022

\section{Cite This Paper in the following Citation Styles}

(a): [1] Nnam Imaobong Judith, Amara Felix Maduabuchi, Ekete Linus Igwe, Okeke Stella Ehis, Chukwunwike Onyekachi David, "Taxation Practices and the Survival of Small and Medium-Sized Enterprises (SMEs)," Universal Journal of Accounting and Finance, Vol. 10, No. 2, pp. 399 - 410, 2022. DOI: 10.13189/ujaf.2022.100204.

(b): Nnam Imaobong Judith, Amara Felix Maduabuchi, Ekete Linus Igwe, Okeke Stella Ehis, Chukwunwike Onyekachi David (2022). Taxation Practices and the Survival of Small and Medium-Sized Enterprises (SMEs). Universal Journal of Accounting and Finance, 10(2), 399 - 410. DOI: 10.13189/ujaf.2022.100204.

Copyright $\odot 2022$ by authors, all rights reserved. Authors agree that this article remains permanently open access under the terms of the Creative Commons Attribution License 4.0 International License

\begin{abstract}
Small and Medium-sized Enterprises (SMEs) serve as vital economic stimulators in developing and developed economies. However, several factors including high energy costs and taxing practices hamper these businesses growth and expansion. Essentially, taxation or taxing practices are those multiple payments obligations placed on SMEs by the state. This study examined the effect of taxation/taxing practices on the growth of SMEs with a specific focus on whether 'multiple payment obligations placed on SMEs have significant implications on their profitability, investment decisions, and cash flows. The study adopted survey research design. The chi-square and regression analysis were used in testing hypotheses. Results from the chi-square and regression analysis indicated that tax practices significantly affect SMEs profitability and investment decisions. However, on the effect of taxation on the cash flow of SMEs, the chi-square test showed a non-significant effect of taxation on cash flow while the regression analysis revealed a significant relationship between taxation and cash flow of SMEs. This contradiction may be ascribed to bias exhibited by some respondents in answering some questions asked during the survey. Therefore, the study recommended that the government improves on tax incentive already provided, improve infrastructure, and implement tax policies based on the ability to pay and eschew multiplicity of payment by SME owners; these will eventually encourage growth and expansion of SMEs and the economy at large.
\end{abstract}

Keywords Taxation, Growth, Tax Policies, SMEs, Taxation Practice

\section{Introduction}

As an indispensable tool of the government, taxation helps facilitate and regulate general economic activities in a country. It is the compulsory levies imposed by the government on business profits, personal income, dividends, and commissions necessary for the infrastructural and social development of the country [1]. It has three main objectives: raising revenue for government expenditure, controlling the economy and economic activities, and regulating income and employment. These objectives specifically include raising revenue, reducing inequality in the economy, regulating the consumption of certain goods, curbing inflation, servicing the national debt, planning and directing the economy, protecting infant industries, promoting exports and curtailing imports, and maintaining credit balance [2].

Some basic principles otherwise known as tax policies guide the tax system and practice, without which it will not operate efficiently and effectively. A poorly executed tax system may lead to poor efficiency, high collection charges, waste of time for the taxpayer and the staff, insufficient tax revenue and the deviation of optimum allocation of resources [3]. This necessitated the proposal of some taxation canons (economy, certainty, convenience, and universality) by tax scholars, for example, Adams Smith.

Concurrently, SMEs are catalysts for national economic 
growth and development [4]. Also, the SMEs sector is considered crucial enhancing the private sector contribution and provides the critical building blocks for industrialization and sustainable economic growth [5]. Ani [6] observes that SMEs contributes massively in developed nations. In his opinion, SMEs accounted for about $20 \%$ of innovation in bio-technology-related fields in Europe in 2014. Similarly, they are also known to account for over 95\% of businesses, 60 to $70 \%$ employment, $55 \%$ of Gross Domestic Product (GDP) and generate a large proportion of new employment opportunities [6].

The government is said to be a catalyst for the promotion of growth and development of businesses, especially SMEs. The advanced economies of the world attained advanced industrial development because they started with programmes that encouraged SMEs. These SMEs contribute to long-run industrial growth by producing an increasing number of businesses that grow out of the small scale level of business development. In Nigeria, the government is advocating for an increase in the growth rate of GDP, a stable general price level, increased employment opportunities, etc. through the establishment of SMEs. However, these cannot be actualized if effective programmes, especially regarding to taxation practices, are not established and implemented to encourage sustainable business growth and development.

Taxation practices are essentially those multiple payments obligations placed on SMEs by the state. Taxation/taxing practices on SMEs coupled with inadequate provision of social infrastructure poses a threat that these businesses may not be able to survive the harsh economic condition. Often, it results in a reduction of their operating capacity and the worst-case scenario, their failure. Therefore, the general economy suffers from this in terms of, slowed GDP growth, general price instability, adverse balance of payment position, possible loss in value of the national currency, and reduction in employment opportunities, which may result in security issues to the detriment of the nation at large.

Recognizing the enormous potential contributions of SMEs to economic growth and development, concerning the strategic role taxation plays in facilitating the affairs of governments, one is tempted to ask if the taxation practices on SMEs have a desirable or undesirable effect on the operational capacity of SMEs. That is, how does taxation affect the investment, profitability, growth and expansion of SMEs in Enugu State? Does it impede or enhance the capacity of the SMEs to grow and expand their operations? This becomes the core concern of this study. Specifically, the study examined how taxation affects the profitability of SMEs, the extent to which taxation affects the investment decisions of SMEs, and the extent to which taxation affects the cash flow of SMEs. Therefore, hypotheses for this study include: (i) Taxation practices have a significant effect on the profitability of SMEs; (ii) The extent to which taxation affects investment decisions of SMEs is significant; (iii) The extent to which taxation affects the cash flow of SMEs is significant. The terms taxation and taxation/taxing practices are used interchangeably.

\section{Literature Review}

In the words of Tabet and Onyeukwu [1], taxes are compulsory levies imposed by the government on business profits, personal income, dividends, and commissions necessary for the infrastructural and social development of the country. These taxes imposed by the government benefit the public in general rather than just those who bear the burden. The objectives of taxation include raising revenue, reducing inequality, regulating and controlling the consumption of certain goods, checking inflation, servicing the national debt, planning and directing the economy, protecting infant industries, promoting exports and curtailing imports, maintaining credit balance, etc. [2].

As a major source of revenue to the government, it should therefore ensure that all possible strategies are employed in maximizing revenue from taxation. However, in maximizing revenue received from taxation, the government should ensure that it takes cognizance of the effect of every form of taxation on economic agents and the economy at large. In this regard, Yadviga [7] posits that a correct level of taxation, as well as the simplicity requirements of taxation, will lead to a higher development of the SME sector that will in its turn cause an increase in the degree of competitiveness of the economy, a rise in production, and a more stable government revenue. Tax policies should, therefore, be consistent with general economic policies, such that, it encourages savings and investment instead of consumption.

\subsection{Taxation and What Constitutes a Good Tax System}

Smith [8] propounded the four canons of taxation that is today called the fundamental principles of taxation. This shaped the economic schools of thought regarding taxation from the days of Adam Smith and remains relevant today. These canons include Equity/Ability, Certainty, Economy and Convenience. The canon of equity implies that the criterion for the imposition of taxes should be the ability to pay, and the sacrifice caused by taxation should be equal for everyone. The canon of certainty implies that the taxpayer should be certain about their tax liability. Meaning, the basis and rates of taxation should be clearly defined. Also, a good tax system should be such that the cost of collecting tax revenue should be as low as possible according to the canon of economy. If a large proportion of tax collected is used in defraying the cost of collection, such a tax system is said to be uneconomical and inefficient. Lastly, the canon of convenience states that the time and the mode of payment of taxes should be such that it causes minimum inconvenience to the taxpayer.

The administration of taxation in Nigeria is along the tier system in which the country is governed. Meaning, the 
Federal, State and Local government have their unique taxing powers and jurisdiction, making the tax net wider in coverage [9]. This potential coverage of the tax net creates room for tax malpractices. For example, SMEs in the Enugu metropolis suffer multiple payments of unexplained charges duly receipted by the State and Local governments, within and outside the conventional taxes. Also, the tax assessment and collection procedures in Nigeria alongside Enugu state are very cumbersome. In the opinion of Ndulue [10], as cited in Nwamuo [11], the Nigerian tax system does not meet all these requirements i.e. the canons. More so, the time and manner of payment are not clear to the taxpayer, especially, the self-employed [11]. Also, the Federal Ministry of Finance (FMF) [9] lamented that overlap of tax boundaries is a challenge to tax administration, maybe because any case of overlap is suffered by the taxpayer who is usually not refunded at the end of all tax reconciliation.

\subsection{The concept of SME}

According to Sule [12] as cited in Tabet and Onyeukwu [1], a Small Scale Enterprise is an entity with a labour size of 1-100 workers or a total cost of not more than $\$ 50$ million (122,000 USD) including working capital but excluding the cost of land; while a Medium Scale Enterprise is an entity with a labour size of $101-300$ workers or total cost of over $\$ 50$ million (122,000 USD) but not more than $\$ 200$ million (490,000 USD) including working capital but excluding the cost of land. The study also stated that about $50 \%$ are engaged in distributive trade, $10 \%$ in manufacturing, $30 \%$ in agriculture and the rest $10 \%$ in services.

Meanwhile, the Finance Act (2020) recognises small businesses for corporate tax liability, as companies with annual gross turnover of $\mathrm{N} 25$ million $(61,000$ USD) or less and medium-sized companies as businesses having annual gross turnover between N25 million (61,000 USD) and N100 million (244,000 USD) [13]. This study adopted the definition as given by Sule [12] in Tabet and Onyeukwu [1] and will base its survey, findings and conclusions in that regard.

\subsubsection{Relevance, Problems/Challenges of SMEs to National Economy}

The Nigerian economy has depended so much on the oil sector that it has not fully harnessed the benefits that could be offered by the SME sectors. SMEs ensure the provision of employment, alleviation of poverty, proper allocation of resources and contribution to national GDP. SMEs cannot be eliminated in an economy because of the irreplaceable role it plays in economic growth and development.

In a study by Keskg̀n, Sentürk, Sungur, and Kiris, [14], it was opined that the SME sector has become the main driving force behind job creation, poverty alleviation, income distribution, development of entrepreneurship, production of intermediate goods and transformation of indigenous technology in every economy, development of entrepreneur and avenue for self-employment and provision of opportunity for training managers and semi-skilled workers. Also, Tang, Paul and Yuli [15] in Tabet and Onyeukwu [1] added that China is fast becoming the largest economy in the world and SMEs are the key element in China's economy accounting for $99 \%$ of the total number of firms and about $70 \%$ of overall employment

Given the significant contributions of the SME sector to national growth and development, the Nigerian government has developed some institutions, agencies or policies to enhance the development of SMEs in Nigeria [16]. These efforts of the government are commendable but the major problem lies in their implementation [17]. Aderemi [18] as cited in Ojeka [19] also observed that SMEs are faced with several challenges, such as; reluctance of banks to lend to them, promoters' low education, poor management and entrepreneurial skills and unreliable financial records which makes financial review difficult. Uzor [20] in Ocheni and Gemade [21] added that the constraints faced by SMEs in developing countries are not only accentuated with ineffective policy design, but also by market failures in the region. Ojeka [19] deviating from what was observed by other scholars, iterated that most SMEs are faced with the problem of high tax rates, multiple taxations, complex tax regulations and lack of proper enlightenment or education about tax and related issues.

Taxes/levies collected from small businesses in Enugu state include, but are not limited to; Business premises, Advert permit fee, Personal income tax, Local government levy, Sanitation levy (ESWAMA), Shop permit fee, Radio $\&$ Television license fee, Special security levy, Business permit fee, Fire safety revenue, signpost permit fee, development levy, Liquor license, Motor park levies, Value added tax, Withholding tax, Wheelbarrow permit, Hawker permit, etc.

\subsection{Theoretical Framework}

The ability to pay principle originated in the sixteenth century and was extended by Jean Jacques Rousseau, Jean-Baptiste Say and John Stuart Mill. This theory states that taxes collected by the government should emanate from those who can bear the burden of such taxes i.e. taxes should be collected from individuals following their capacity to pay such taxes.

Several theories of business growth exist. However, this study is in line with the theory of business growth represented in Olawale and Garwe [22]. The business growth theory opined that as a small firm commences and develops, it passes through some stages of growth, and each of these stages has its distinctive characteristics. He identified these stages of growth as; existence, survival, success, take-off and resource maturity. Therefore, the 
overburdening (taxing) of a business trying to survive the difficult process of survival is not in the best of any state or national economy.

\subsection{Empirical Review}

In a study carried out by Ojeka [19] on "Tax policy and the growth of SMEs: Implications for the Nigerian economy", it was discovered that the lower the amount of taxes paid by SMEs, the higher the amount of growth-related investments the profits are used for. The study, therefore, concluded that for SMEs to flourish, an appropriate tax policy that will not be an impediment to SMEs and which will enhance voluntary compliance should be put in place. The position of Ojeka [19] is supported by Ojochogwu and Ojeka [23], in their study titled, the relationship between tax policy, growth of SMEs and the Nigerian economy. The study likewise revealed that the higher the amount of tax paid by SMEs, the lower the funds available for re-investment and this, therefore, leads to a slow rate of business expansion.

Ocheni [3] conducted a study on "Impact analysis of tax policy and the performance of Small and Medium Scale Enterprises in Nigerian economy" in which he concluded that the best tax policy for SMEs is one that lowers compliance and administrative costs, reduces uncertainty faced by taxpayers, and improves the level of voluntary compliance. He, therefore, among other recommendations, stated that tax policies should be designed in a manner that will encourage those who are potential taxpayers, voluntary compliance and these will eventually lead to expansion of existing business interests of the SMEs in Nigeria.

Assessing the effect of multiple taxations on SMEs' performance in Benue State using the survey design, Ocheni and Gemade [21] postulated that multiple taxations affect the growth and survival of SMEs in Benue state. They, therefore, among other recommendations, stated the need for SMEs to be levied lower amounts of taxes to ensure that they have enough funds to carry out activities that will result in their growth.

Estimating the effect of tax payment on the performance of SMEs in Ghana West Municipal Assembly, Tee, Boadi and Opoku [24] using several analytical tools such as correlation, regression, amongst others, discovered that the higher the tax incentives towards SMEs, the lesser the negative influence of tax on purchases made by them. The same study also established that SMEs are not aware of tax reliefs by the government towards them and therefore these reliefs were found to have an insignificant effect on the profitability of SMEs.

Okolo, Okparaojiego and Okolo [25] in their work titled, "Effect of multiple taxations on investment in SMEs in Enugu State, Nigeria" postulated that there is a significant relationship between SMEs' investment and their ability to pay tax and that multiple taxations affect SMEs' investment negatively. They recommended among other, that the government should prioritize the SME sector as a matter of urgency.

Nwamuo's [11] study on multiple taxations and the operations of business enterprises in Aba metropolis discovered that there is clear evidence of multiple taxations of businesses in Aba metropolis. He further stated that this incidence of multiple taxations has resulted in an increased cost of operations for businesses and a reduction in the employment capacity of businesses.

Agot and Ugwuoke [26], in their study of taxation and the growth of Small and Medium Scale Enterprise (SMEs) in Nasarawa state using cause-effect design, revealed that a high tax system alongside unfavourable tax policies harms the growth of SMEs in Nasarawa state and by implication, the entire nation. They maintained that the profit, capital and employment capacity of SMEs has drastically reduced as a result of the heavy tax burden which hinders their growth and development.

Cross [27] carried out a study on the "Effect of Multiple Taxation on SMEs in Nigeria" which concluded that there exists a relationship between SMEs' sizes and their ability to pay taxes, multiple taxations and SMEs survival. The study recommended that taxes should be collected considering the sizes and profits of SMEs.

A study was carried out by Tabet and Onyeukwu [1] with the title, "Multiple taxation and Small and Medium Scale Enterprises (SMEs) financial performance in Abuja, Nigeria. The study concluded that there exists a strong relationship between multiple taxations and the financial performance of SMEs in Abuja, Nigeria.

To the best of our knowledge, it has been discovered that most studies in this area have examined all kinds of SMEs in many sectors/industries and at different stages of development at the same time. This study fills this gap by focusing on SMEs in the trade and services sector and their early (cradle) stages of development.

\section{Methodology}

Given the nature of this study, the survey research design was adopted. It is a technique of investigation that involves direct observation of or gathering data from the population when adequate information is not available on records, files or other sources. It is an important tool when gathering evidence relating to a certain social problem [28]. Also, the survey method is effective when it comes to getting opinions, attitudes and descriptions, as well as, obtaining cause and effect relationships [29]. The data for this study were principally obtained from primary sources via personal interviews, and questionnaires. The population of the study comprised of two-hundred and fifty (250) SMEs (Trade sector-150 and service sector-100) within Enugu Metropolis of Enugu State in Nigeria, with an adequate record of taxes, levies or fees paid to the government. Based on the above population, the sample size for the study was determined using Yamane's formulae for sample size determination. This is expressed 
as follows: $\mathrm{n}=\frac{N}{1+N(e)^{2}}$ where, $\mathrm{n}=$ Sample size, $\mathrm{N}=$ Total population and $\mathrm{e}=$ Level of significance which is $5 \%$ or 0.05 .

Substituting, we have: $\mathrm{n}=\frac{250}{1+250(0.05)^{2}}=153.846 \approx 154$ businesses (SMEs).

The collected data was analysed using descriptive statistics such as frequency counts with simple percentages. At the inferential level of data analysis, chi-square test and regression analysis were used to test this study's hypotheses.

The questionnaire was designed to elicit the specifically required information from the respondents [30]. The use of regression analysis was informed by the fact that it is a valid instrument for estimating the relationship between a dependent and one or more independent variables. Also, the chi-square test is a well-known tool for testing statistical significance [31]. To ensure the reliability of the research instrument adopted, the test-re-test method was adopted in which twenty (20) copies of the questionnaire were distributed to properly selected SMEs in the Enugu metropolis. These copies were recollected and another set of copies was redistributed to the same group of selected SMEs. This established some degree of consistency in responses.

\section{Presentation and Analysis of Data}

The table 1 shows the observed and expected frequencies in specified categories with the expected frequencies being enclosed in a bracket. There are five questions for each of the three objectives of this study and chi-square results were generated using responses to five questions asked for each objective. (see Appendix I).

The table 2 represents a summary of the results of regression analysis conducted using the data displayed in Appendix II of this work with the aid of SPSS statistical software.

Table 1. Summary of responses obtained during survey under specified categories

\begin{tabular}{|c|c|c|c|c|c|}
\hline Questions & Agree & $\begin{array}{c}\text { Strongly } \\
\text { Agree }\end{array}$ & Disagree & $\begin{array}{l}\text { Strongly } \\
\text { Disagree }\end{array}$ & Undecided \\
\hline $\mathrm{Q}_{1}$ & $91(72.4)$ & $15(18.4)$ & $25(35.8)$ & $1(5.4)$ & $0(0)$ \\
\hline $\mathrm{Q}_{2}$ & $67(72.4)$ & $12(18.4)$ & $48(35.8)$ & $5(5.4)$ & $0(0)$ \\
\hline $\mathrm{Q}_{3}$ & $82(72.4)$ & $18(18.4)$ & $27(35.8)$ & $5(5.4)$ & $0(0)$ \\
\hline $\mathrm{Q}_{4}$ & $55(72.4)$ & $25(18.4)$ & $44(35.8)$ & $8(5.4)$ & $0(0)$ \\
\hline $\mathrm{Q}_{5}$ & $67(72.4)$ & $22(18.4)$ & $35(35.8)$ & $8(5.4)$ & $0(0)$ \\
\hline $\mathrm{Q}_{6}$ & $69(77.8)$ & $9(16.8)$ & $35(24.8)$ & 19 (11.6) & $0(1)$ \\
\hline $\mathrm{Q}_{7}$ & $82(77.8)$ & $22(16.8)$ & $21(24.8)$ & $5(11.6)$ & $2(1)$ \\
\hline $\mathrm{Q}_{8}$ & 78 (77.8) & $13(16.8)$ & $28(24.8)$ & 13 (11.6) & $0(1)$ \\
\hline $\mathrm{Q}_{9}$ & $70(77.8)$ & 27 (16.8) & $25(24.8)$ & $9(11.6)$ & $1(1)$ \\
\hline $\mathrm{Q}_{10}$ & $90(77.8)$ & $13(16.8)$ & $15(24.8)$ & 12 (11.6) & $2(1)$ \\
\hline $\mathrm{Q}_{11}$ & $83(78.2)$ & $13(18.4)$ & $29(28.4)$ & $7(5.6)$ & $0(1.4)$ \\
\hline $\mathrm{Q}_{12}$ & $80(78.2)$ & 17 (18.4) & $26(28.4)$ & $7(5.6)$ & $2(1.4)$ \\
\hline $\mathrm{Q}_{13}$ & $72(78.2)$ & $30(18.4)$ & $25(28.4)$ & $5(5.6)$ & $0(1.4)$ \\
\hline $\mathrm{Q}_{14}$ & $80(78.2)$ & 17 (18.4) & $28(28.4)$ & $6(5.6)$ & $1(1.4)$ \\
\hline $\mathrm{Q}_{15}$ & $76(78.2)$ & 15 (18.4) & 34 (28.4) & $3(5.6)$ & $4(1.4)$ \\
\hline
\end{tabular}

Source: Field Survey, 2021

Table 2. Summarized results of regression analysis

\begin{tabular}{|c|c|c|c|c|c|c|}
\hline Hypotheses & Regression Weight & $\begin{array}{c}\text { Beta } \\
\text { Coefficient }\end{array}$ & $\mathbf{R}^{\mathbf{2}}$ & $\mathbf{F}$ & p-value & $\begin{array}{c}\text { Accept/Reject } \\
\text { Null Hypothesis }\end{array}$ \\
\hline Hypothesis one & Taxation $\rightarrow$ Profit & 2.524 & .465 & 113.098 & .000 & Reject \\
\hline Hypothesis two & Taxation $\rightarrow$ Investment & -1.950 & .534 & 149.198 & .000 & Reject \\
\hline Hypothesis three & Taxation $\rightarrow$ Cashflow & -2.701 & .496 & 128.050 & .000 & Reject \\
\hline
\end{tabular}

Source: SPSS Version 25 


\subsection{Discussion of Results}

Hypothesis one was tested using chi-square and regression analysis to ascertain whether taxation has a significant effect on the profitability of SMEs. The result from the chi-square test reveals that taxation has a significant effect on the profitability of SMEs (X2 = 26.296 $<\mathrm{X} 2 \mathrm{o}=34.596)$. This aligns with the result from the regression analysis which indicates that taxation significantly predicts variations in the profit of SMEs, $\mathrm{F}=$ $113.10, \mathrm{p}=.000, \mathrm{R} 2=.47, \mathrm{~B}=2.52$. The two results above are in agreement with Nwamuo [11] study on multiple taxations and the operations of business enterprises in Aba metropolis. The study showed that taxes and levies imposed by the government have resulted in increased cost of business operations in Aba metropolis and discouraged investment in businesses.

In testing hypothesis two, chi-square and regression analysis were used to determine whether the extent to which taxation affects the investment decisions of SMEs is significant. The result from the chi-square test shows that the extent to which taxation affects investment decisions of SMEs is significant $(\mathrm{X} 2=26.296<\mathrm{X} 2 \mathrm{o}=39.366)$. This agrees with the regression analysis result which indicates that taxation significantly predicts variations in the profit of SMEs, $\mathrm{F}=149.20, \mathrm{p}=.000, \mathrm{R} 2=.53$. The regression coefficient $(B=-1.95)$, explains that an increase in taxation, corresponds on average, to a decrease in the investment of 1.95 points. The results above are in line with a study by Ojeka [19] and Ojochogwu and Ojeka [23]. The result showed that the lower the amount of taxes paid by SMEs, the greater the growth-related projects their profits are used for. The study also, stated that SMEs should be levied lower amounts of taxes to enable them to have enough funds for other investment activities that will lead to business growth.

Using chi-square and regression analysis, hypothesis three was tested to ascertain whether the extent to which taxation affects the cash flow of SMEs is significant. The result from the chi-square test reveals that the extent to which taxation affects the cash flow of SMEs is not significant $(\mathrm{X} 2=26.296>\mathrm{X} 2 \mathrm{o}=22.402)$. This is in contrast with the result from the regression analysis which shows that taxation significantly predicts variations in the cash flow of SMEs, $\mathrm{F}=128.10, \mathrm{p}=.000, \mathrm{R}^{2}=.50$. The regression coefficient $(B=-2.7)$, indicates that an increase in taxation, corresponds on average, to a decrease in cash flow of 2.7 points.

\subsection{Summary of Empirical Findings}

Based on analysis of data collected via a questionnaire administered to SMEs in Enugu state and testing of hypotheses, the findings of this study are as follows:

(a) Taxation has a significant effect on the profitability of SMEs. (b) The extent to which taxation affects investment decisions of SMEs is significant

(c) The extent to which taxation affects the cash flow of SMEs is not significant.

\section{Conclusions and Recommendations}

a. Despite the strategic role of SMEs in Enugu state, Nigeria, and the world economy as a key economic stimulator in terms of facilitating the introduction of innovations, providing employment opportunities and general transformation of the economy, they still face numerous challenges, a major of which is high tax burden, especially by the state and local governments. From the results of this study, it can be precisely deduced that taxation practices have a considerable effect on the growth of SMEs in Enugu state, Nigeria.

b. The 'ability to pay' of every SME should be given a priority consideration before the payment burden is placed on the SME. Particularly as the expansion and contribution of the SME are greatly dependent on her cash inflows, profitability and reinvestment; the lesser the financial burden on SME, the better the chances of profitability, reinvestment and expansion of the SME and the better the national economy.

c. Based on the findings of this study, the following recommendations are made: (i) The number/amount of taxes, and payments collected from SMEs, especially by the lower tiers of government should be reduced and made a single charge, to enable them to reinvest a larger portion of their profit into the business for expansion. (ii) Government should ensure that SMEs are given tax incentives when they invest in new equipment, machinery, or innovative technologies that can enhance growth and expansion. (iii) There is a need for the government to look into factors that may affect the growth of SMEs, such as the provision of adequate infrastructure which will immensely reduce their cost of operation. (iv) Government tax policies based on the ability to pay should not just be introduced but also, followed through its full implementation.

d. The study considered SMEs in the Enugu metropolis of Enugu state of Nigeria i.e. an emerging economy. A comparative study of taxation practices on SMEs in emerging economies would give a more universal view of the subject.

\section{Appendix I (Questionnaire Administered)}

Guide: Please tick the option which matches your opinion. 


\section{Section A}

1. What sector does your business belong to? [A] Trade [B] Services [C] Other

2. The nature of business [A] Small scale [B] Medium scale

\section{Section B}

PLEASE NOTE: Use the responses of Strongly Agree $(\mathrm{SA})=5$, Agree $(A)=4$, Undecided $(\mathrm{U})=3$, Disagree $(\mathrm{D})=2$, Strongly Disagree $(\mathrm{SD})=1$.

\begin{tabular}{|c|c|c|c|c|c|c|}
\hline $\mathbf{S} / \mathbf{N}$ & QUESTIONNAIRE ITEMS & SA & $\mathbf{A}$ & D & SD & $\mathbf{U}$ \\
\hline & $\begin{array}{l}\text { To examine how taxation affects the profitability of Small and Medium-sized Enterprises } \\
\text { (SMEs) }\end{array}$ & & & & & \\
\hline 1 & $\begin{array}{l}\text { Taxes have been a major cost component thereby reducing the profit of Small and Medium-sized } \\
\text { Enterprises(SMEs). }\end{array}$ & & & & & \\
\hline 2 & $\begin{array}{l}\text { Taxes have discouraged SMEs from increasing their sales, thereby reducing the chances of increasing } \\
\text { profit. }\end{array}$ & & & & & \\
\hline 3 & $\begin{array}{l}\text { Taxes paid by SMEs reduce their efficiency, thereby leading to a decline in the profit generated by } \\
\text { SMEs. }\end{array}$ & & & & & \\
\hline 4 & $\begin{array}{l}\text { Taxes paid by SMEs have caused them to increase the prices of their goods/services leading to a } \\
\text { reduction in demand and consequently, profit generated by them. }\end{array}$ & & & & & \\
\hline \multirow[t]{2}{*}{5} & $\begin{array}{l}\text { Taxes have reduced the ability of SMEs to introduce innovative ways of doing business, thereby } \\
\text { reducing their ability to expand profit generation capacity. }\end{array}$ & & & & & \\
\hline & $\begin{array}{l}\text { To examine the extent to which taxation affects investment decisions of Small and } \\
\text { Medium-sized Enterprises (SMEs) }\end{array}$ & & & & & \\
\hline 6 & Taxes paid by SMEs affect their ability to make investments in new equipment and machinery. & & & & & \\
\hline 7 & $\begin{array}{l}\text { Taxes paid by SMEs affect their ability to expand their operations by the introduction of new } \\
\text { products/services. }\end{array}$ & & & & & \\
\hline 8 & $\begin{array}{l}\text { Taxes paid by SMEs reduce their income to an extent that such taxes affect SMEs' ability to introduce } \\
\text { new technology to their businesses. }\end{array}$ & & & & & \\
\hline 9 & Taxes paid by SMEs affect their ability to replace worn-out equipment and machinery. & & & & & \\
\hline \multirow[t]{2}{*}{10} & $\begin{array}{l}\text { Taxes paid by SMEs affect their ability to expand their operations by the introduction of their } \\
\text { products/services into a new market and servicing such a market. }\end{array}$ & & & & & \\
\hline & $\begin{array}{l}\text { To examine the extent to which taxation affects the cash flow of Small and Medium-sized } \\
\text { Enterprises (SMEs) }\end{array}$ & & & & & \\
\hline 11 & Taxation causes a major reduction in the cash available from operations in SMEs & & & & & \\
\hline 12 & $\begin{array}{l}\text { Indirect taxes lead to increased prices of goods/services which results in a fall in demand and cash } \\
\text { inflow }\end{array}$ & & & & & \\
\hline 13 & Taxation results in a serious decline in the working capital available to SMEs & & & & & \\
\hline 14 & Taxation causes a decline in cash available to SMEs for funding capital projects & & & & & \\
\hline 15 & Taxation causes a serious reduction in cash available to SMEs for funding their financial obligations & & & & & \\
\hline
\end{tabular}

\section{Section C}

1. Average annual taxes paid for the past five years (
(a) Between 0 to 1 million
(b) Between 1 to 2 million
(c) Between 2 to 3 million
(d) Between 3 to 4 million
(e) Between 4 to 5 million
(f) Between 5 to 6 million
(g) Between 6 to 7 million
(h) Between 7 to 8 million
(i) Above 8 million

2. Average annual profit for the past five years (
(a) Between 0 to 3 million
(b) Between 3 to 6 million
(c) Between 6 to 9 million
(d) Between 9 to 12 million
(e) Between 12 to 15 million
(f) Between 15 to 18 million
(g) Between 18 to 21 million
(h) Between 21 to 24 million

(i) Above 24 million

3. Average annual investment for the past five years (
(a) Between 0 to 2 million
(b) Between 2 to 4 million
(c) Between 4 to 6 million
(d) Between 6 to 8 million
(e) Between 8 to 10 million
(f) Between 10 to 12 million
(g) Between 12 to 14 million
(h) Above 14 million

4. Average annual net-cash flow for the past five years (\#)
(a) Between 0 to 3 million
(b) Between 3 to 6 million
(c) Between 6 to 9 million
(d) Between 9 to 12 million
(e) Between 12 to 15 million
(f) Between 15 to 18 million
(g) Between 18 to 21 million
(h) Above 21 million 


\section{Appendix II}

Average five-year taxation, profit, investment and net-cash flow of SMEs surveyed

\begin{tabular}{|c|c|c|c|c|c|}
\hline S/No & Nature of Business & $\begin{array}{c}\text { Average taxation } \\
\left(N^{\prime} M\right)\end{array}$ & $\begin{array}{c}\text { Average profit } \\
\text { (स'M) }\end{array}$ & $\begin{array}{c}\text { Average Investment } \\
\left(\mathbf{N}^{\prime} \mathbf{M}\right)\end{array}$ & $\begin{array}{c}\text { Average net-cash flow } \\
\left(\mathrm{N}^{\prime} M\right)\end{array}$ \\
\hline 1 & Small scale & 0.5 & 1.5 & 3 & 4.5 \\
\hline 2 & Small scale & 0.5 & 4.5 & 3 & 7.5 \\
\hline 3 & Small scale & 1.5 & 4.5 & 1 & 1.5 \\
\hline 4 & Small scale & 1.5 & 1.5 & 1 & 1.5 \\
\hline 5 & Small scale & 0.5 & 4.5 & 5 & 7.5 \\
\hline 6 & Small scale & 0.5 & 4.5 & 5 & 4.5 \\
\hline 7 & Small scale & 1.5 & 7.5 & 1 & 1.5 \\
\hline 8 & Medium-scale & 1.5 & 7.5 & 1 & 1.5 \\
\hline 9 & Medium-scale & 2.5 & 7.5 & 1 & 1.5 \\
\hline 10 & Small scale & 0.5 & 1.5 & 5 & 7.5 \\
\hline 11 & Medium-scale & 1.5 & 4.5 & 1 & 4.5 \\
\hline 12 & Small scale & 1.5 & 1.5 & 1 & 1.5 \\
\hline 13 & Small scale & 0.5 & 4.5 & 5 & 7.5 \\
\hline 14 & Small scale & 1.5 & 4.5 & 1 & 1.5 \\
\hline 15 & Medium-scale & 2.5 & 7.5 & 1 & 1.5 \\
\hline 16 & Small scale & 0.5 & 4.5 & 7 & 7.5 \\
\hline 17 & Small scale & 1.5 & 4.5 & 1 & 1.5 \\
\hline 18 & Medium-scale & 2.5 & 10.5 & 3 & 4.5 \\
\hline 19 & Small scale & 0.5 & 4.5 & 5 & 7.5 \\
\hline 20 & Small scale & 1.5 & 7.5 & 1 & 1.5 \\
\hline 21 & Small scale & 0.5 & 1.5 & 5 & 10.5 \\
\hline 22 & Medium-scale & 2.5 & 4.5 & 1 & 1.5 \\
\hline 23 & Medium-scale & 0.5 & 4.5 & 5 & 4.5 \\
\hline 24 & Small scale & 0.5 & 4.5 & 7 & 10.5 \\
\hline 25 & Medium-scale & 1.5 & 10.5 & 3 & 1.5 \\
\hline 26 & Small scale & 0.5 & 4.5 & 7 & 4.5 \\
\hline 27 & Medium-scale & 2.5 & 10.5 & 1 & 1.5 \\
\hline 28 & Small scale & 0.5 & 7.5 & 5 & 4.5 \\
\hline 29 & Medium-scale & 1.5 & 7.5 & 1 & 4.5 \\
\hline 30 & Small scale & 0.5 & 1.5 & 5 & 7.5 \\
\hline 31 & Medium-scale & 1.5 & 7.5 & 3 & 1.5 \\
\hline 32 & Small scale & 0.5 & 4.5 & 5 & 7.5 \\
\hline 33 & Medium-scale & 0.5 & 7.5 & 7 & 7.5 \\
\hline 34 & Small scale & 0.5 & 4.5 & 5 & 4.5 \\
\hline 35 & Small scale & 0.5 & 4.5 & 5 & 7.5 \\
\hline 36 & Medium-scale & 1.5 & 4.5 & 1 & 1.5 \\
\hline 37 & Small scale & 0.5 & 4.5 & 5 & 10.5 \\
\hline 38 & Small scale & 1.5 & 7.5 & 3 & 1.5 \\
\hline 39 & Small scale & 0.5 & 1.5 & 3 & 4.5 \\
\hline 40 & Medium-scale & 0.5 & 7.5 & 5 & 7.5 \\
\hline 41 & Small scale & 0.5 & 4.5 & 5 & 7.5 \\
\hline 42 & Medium-scale & 1.5 & 7.5 & 3 & 1.5 \\
\hline
\end{tabular}


Table Continued

\begin{tabular}{|c|c|c|c|c|c|}
\hline 43 & Small scale & 0.5 & 4.5 & 3 & 7.5 \\
\hline 44 & Medium-scale & 2.5 & 10.5 & 3 & 1.5 \\
\hline 45 & Small scale & 0.5 & 4.5 & 5 & 4.5 \\
\hline 46 & Small scale & 0.5 & 1.5 & 3 & 4.5 \\
\hline 47 & Medium-scale & 1.5 & 7.5 & 1 & 1.5 \\
\hline 48 & Small scale & 0.5 & 4.5 & 7 & 4.5 \\
\hline 49 & Medium-scale & 2.5 & 10.5 & 3 & 1.5 \\
\hline 50 & Small scale & 0.5 & 1.5 & 5 & 4.5 \\
\hline 51 & Small scale & 0.5 & 7.5 & 5 & 7.5 \\
\hline 52 & Small scale & 0.5 & 1.5 & 5 & 4.5 \\
\hline 53 & Medium scale & 1.5 & 1.5 & 1 & 7.5 \\
\hline 54 & Small scale & 0.5 & 1.5 & 3 & 7.5 \\
\hline 55 & Small scale & 0.5 & 7.5 & 5 & 7.5 \\
\hline 56 & Small scale & 0.5 & 1.5 & 5 & 4.5 \\
\hline 57 & Medium-scale & 1.5 & 7.5 & 1 & 4.5 \\
\hline 58 & Small scale & 0.5 & 4.5 & 5 & 7.5 \\
\hline 59 & Small scale & 0.5 & 1.5 & 5 & 7.5 \\
\hline 60 & Medium-scale & 1.5 & 4.5 & 1 & 1.5 \\
\hline 61 & Small scale & 0.5 & 1.5 & 5 & 4.5 \\
\hline 62 & Medium-scale & 1.5 & 7.5 & 3 & 1.5 \\
\hline 63 & Small scale & 0.5 & 1.5 & 3 & 4.5 \\
\hline 64 & Small scale & 0.5 & 4.5 & 3 & 7.5 \\
\hline 65 & Medium-scale & 1.5 & 7.5 & 1 & 4.5 \\
\hline 66 & Small scale & 0.5 & 1.5 & 5 & 7.5 \\
\hline 67 & Medium-scale & 1.5 & 7.5 & 1 & 1.5 \\
\hline 68 & Small scale & 0.5 & 4.5 & 5 & 4.5 \\
\hline 69 & Medium-scale & 2.5 & 7.5 & 1 & 4.5 \\
\hline 70 & Small scale & 0.5 & 1.5 & 5 & 7.5 \\
\hline 71 & Medium-scale & 1.5 & 4.5 & 1 & 1.5 \\
\hline 72 & Small scale & 0.5 & 4.5 & 3 & 7.5 \\
\hline 73 & Medium-scale & 1.5 & 4.5 & 3 & 1.5 \\
\hline 74 & Small scale & 0.5 & 1.5 & 5 & 10.5 \\
\hline 75 & Medium-scale & 1.5 & 7.5 & 1 & 1.5 \\
\hline 76 & Medium-scale & 2.5 & 10.5 & 1 & 4.5 \\
\hline 77 & Small scale & 0.5 & 1.5 & 5 & 7.5 \\
\hline 78 & Small scale & 0.5 & 4.5 & 5 & 4.5 \\
\hline 79 & Small scale & 0.5 & 1.5 & 5 & 4.5 \\
\hline 80 & Medium-scale & 1.5 & 7.5 & 1 & 1.5 \\
\hline 81 & Medium-scale & 1.5 & 4.5 & 3 & 1.5 \\
\hline 82 & Small scale & 0.5 & 4.5 & 5 & 7.5 \\
\hline 83 & Small scale & 0.5 & 4.5 & 7 & 4.5 \\
\hline 84 & Medium-scale & 1.5 & 7.5 & 1 & 4.5 \\
\hline 85 & Medium-scale & 1.5 & 7.5 & 3 & 1.5 \\
\hline 86 & Small scale & 0.5 & 1.5 & 5 & 10.5 \\
\hline 87 & Medium-scale & 2.5 & 7.5 & 3 & 4.5 \\
\hline
\end{tabular}


Table Continued

\begin{tabular}{|c|c|c|c|c|c|}
\hline 88 & Small scale & 0.5 & 4.5 & 5 & 7.5 \\
\hline 89 & Medium-scale & 2.5 & 7.5 & 1 & 1.5 \\
\hline 90 & Small scale & 0.5 & 7.5 & 5 & 4.5 \\
\hline 91 & Medium-scale & 1.5 & 7.5 & 1 & 1.5 \\
\hline 92 & Small scale & 0.5 & 1.5 & 3 & 4.5 \\
\hline 93 & Small scale & 1.5 & 4.5 & 3 & 1.5 \\
\hline 94 & Medium-scale & 2.5 & 10.5 & 3 & 1.5 \\
\hline 95 & Small scale & 0.5 & 4.5 & 5 & 7.5 \\
\hline 96 & Medium-scale & 1.5 & 7.5 & 1 & 4.5 \\
\hline 97 & Small scale & 0.5 & 1.5 & 5 & 10.5 \\
\hline 98 & Medium-scale & 1.5 & 7.5 & 1 & 1.5 \\
\hline 99 & Small scale & 0.5 & 4.5 & 3 & 7.5 \\
\hline 100 & Small scale & 1.5 & 4.5 & 3 & 4.5 \\
\hline 101 & Medium-scale & 1.5 & 7.5 & 1 & 1.5 \\
\hline 102 & Medium-scale & 2.5 & 10.5 & 3 & 1.5 \\
\hline 103 & Small scale & 0.5 & 4.5 & 5 & 7.5 \\
\hline 104 & Small scale & 1.5 & 4.5 & 7 & 7.5 \\
\hline 105 & Medium-scale & 2.5 & 7.5 & 1 & 1.5 \\
\hline 106 & Small scale & 0.5 & 4.5 & 5 & 7.5 \\
\hline 107 & Small scale & 0.5 & 4.5 & 7 & 7.5 \\
\hline 108 & Medium-scale & 2.5 & 10.5 & 3 & 1.5 \\
\hline 109 & Small scale & 0.5 & 1.5 & 7 & 7.5 \\
\hline 110 & Medium-scale & 2.5 & 10.5 & 1 & 4.5 \\
\hline 111 & Small scale & 0.5 & 1.5 & 5 & 10.5 \\
\hline 112 & Medium-scale & 1.5 & 7.5 & 1 & 1.5 \\
\hline 113 & Small scale & 0.5 & 1.5 & 5 & 7.5 \\
\hline 114 & Medium-scale & 2.5 & 10.5 & 1 & 4.5 \\
\hline 115 & Medium-scale & 1.5 & 7.5 & 3 & 1.5 \\
\hline 116 & Small scale & 0.5 & 4.5 & 3 & 7.5 \\
\hline 117 & Small scale & 1.5 & 7.5 & 1 & 1.5 \\
\hline 118 & Medium-scale & 2.5 & 10.5 & 1 & 1.5 \\
\hline 119 & Small scale & 0.5 & 1.5 & 3 & 4.5 \\
\hline 120 & Small scale & 0.5 & 4.5 & 5 & 10.5 \\
\hline 121 & Small scale & 0.5 & 7.5 & 7 & 7.5 \\
\hline 122 & Medium-scale & 2.5 & 4.5 & 1 & 1.5 \\
\hline 123 & Small scale & 0.5 & 7.5 & 5 & 7.5 \\
\hline 124 & Small scale & 0.5 & 7.5 & 7 & 7.5 \\
\hline 125 & Medium-scale & 2.5 & 7.5 & 1 & 4.5 \\
\hline 126 & Medium-scale & 2.5 & 7.5 & 1 & 1.5 \\
\hline 127 & Small scale & 0.5 & 1.5 & 5 & 7.5 \\
\hline 128 & Medium-scale & 1.5 & 4.5 & 1 & 1.5 \\
\hline 129 & Small scale & 0.5 & 1.5 & 5 & 7.5 \\
\hline 130 & Medium-scale & 1.5 & 4.5 & 3 & 1.5 \\
\hline 131 & Small scale & 0.5 & 1.5 & 7 & 7.5 \\
\hline 132 & Small scale & 0.5 & 4.5 & 3 & 7.5 \\
\hline
\end{tabular}

Source: Field Survey, 2021 


\section{REFERENCES}

[1] Tabet, R. \& Onyeukwu P. E., "Multiple Taxation and Small and Medium Scale Enterprises (SMEs) Financial Performance in Abuja, Nigeria," World Journal of Innovative Research (WJIR), vol. 6, no. 2, 2019,

[2] Njoku, P. O., "Public Finance. Sources, Administration and Management" Enugu: El'demak Publishers, 2009

[3] Ocheni, S. I., "Impact Analysis of Tax Policy and the Performance of Small and Medium Scale Enterprises in Nigerian Economy", Strategic Management Quarterly. Vol. 3, no. 1, pp. 71-94, 2015. https://doi.org/10.15640/smq.v3n1a3

[4] Nwonye M. G., "Small and Medium-Scale Enterprises in Nigeria: their Characteristics, Problems and Sources of Finance", 2014, Retrieved from African Economic Research Consortium, http://idl-bnc.idrc.ca/dspace/bitstrea m/10625/9982/1/95971.pdf

[5] Udechukwu, F. N., "Survey of small and medium scale industries and their potentials in Nigeria", Paper presented at the Central Bank of Nigeria seminar on small and medium industries equity investment scheme (SMIEIS), 2003, retrieved from www.cenbank.org/out/Publications/g uidelines/dfd/2014/smieis.pdf

[6] Ani, C., "Tax Policy on SMEs in Nigeria - How fair?" 2017, Retrieved from http://blog.deloitte.com.ng/wp-content/upl oads/2017/12/TaxTake-v3-PRESS.pdf

[7] Yadviga, S., "Taxation of Small and Medium Enterprises", A thesis presented for the award a degree of MA in Economics, 1999.

[8] Smith, A., "Wealth of Nations", Canon's edition, Bk, V, Ch. II, Part II. P. 777-778, 1776.

[9] Federal Ministry of Finance (FMF), "National Tax Policy" (2012), Retrieved 7/5/2017 from http://webcache.googleus ercontent.com/search?q=cache:LC55WAlhuRIJ:9jalegal.c om.Ng/downloads/Articles/Tax/Nationaltax\%2520policy $\% 2520$ document.pdf $+\& \mathrm{~cd}=2 \& \mathrm{hl}=\mathrm{en} \& \mathrm{ct}=\mathrm{clnk} \& \mathrm{gl}=\mathrm{ng}$

[10] Ndulue, J. C., "Private Sector and Generation of Tax Revenue: A case study of federal capital territory, Abuja" (PhD Thesis), 2003.

[11] Nwamuo, C., "Multiple Taxation and the Operations of Business Enterprises in Aba Metropolis", Pyrex Journal of Business and Finance Management Research, vol. 3, no. 6, pp. $132-138,2017$.

[12] Sule, E., "Small Scale Industries in Nigeria concept: an appraisal of Government Policies and Suggestions Solutions to identified problems", CBN Economic and Financial Review, vol. 24, no. 4, 1986.

[13] Uche Nwokedi \& Co. (UNC), "Review of the Finance Act, 2020". Retrieved from https://www.mondaq.com/nigeria/s ales-taxes-vat-gst/904566/review-of-the-finance-act-2020

[14] Keskġn, H., Sentürk, C., Sungur, O., \& Kiris, H. M., "The Importance of SMEs in Developing Economies", $2^{\text {nd }}$
International Symposium on Sustainable Development, June 8-9 2010, Sarajevo. Retrieved on 2/10/21, https://core.ac.uk/download/pdf/153446896.pdf

[15] Tang, Y., Paul, W., \& Yuli, Z., "Marketing and Business Performance of Construction SMEs in China", Journal of Business \& Industrial Marketing, vol. 22, no. 2, pp. 118 $125,2007$.

[16] Ebitu, E. T., Basil, G., \& Ufot, J. A., “An appraisal of Nigeria's Micro, Small and Medium Enterprises (MSMEs): Growth, Challenges and Prospects", British Journal of Marketing Studies, vol. 4, no. 5, pp. 21 - 36, 2016. www.eajournals.org

[17] Alabi, F. A., David, J. O., \& Aderinto, O. C., "The impact of government policies on business growth of SMEs in South Western Nigeria", International Journal of Management Studies and Social Science Research, vol. 1, no. 2, pp. 1 14, 2019. www.ijmsssr.org

[18] Aderemi, A., "Small and Medium Scale Enterprises: The Nigerian Situation", Capital Partners Limited. 2003, Retrieved 12/12/2020, from www.capitalpartnersltd.com/S mall\%20Medium\%20Scale.ppt

[19] Ojeka, S. I., "Tax Policy and the Growth of SMEs: Implications for the Nigerian Economy", Research Journal of Finance and Accounting, vol. 2, no. 2, 2011.

[20] Uzor, O. O. "Small and Medium Scale Enterprises Chester Development in South - Eastern Region of Nigeria", Institute for World Economics and International Management Paper No.86, 2004.

[21] Ocheni, S. I., \& Gemade, T. I., "Effects of Multiple Taxation on the Performance of Small and Medium Scale Business Enterprises in Benue State", International Journal of Academic Research in Business and Social Sciences, vol. 5, no. 3, 2015.

[22] Olawale, F., \& Garwe, D., "Obstacles to the growth of new SMEs in South Africa: a principal component analysis approach", African Journal of Business Management, vol. 4, no. 5, pp. $729-738,2010$.

[23] Ojochogwu, W. A. \& Ojeka, S. A., "Relationship between Tax Policy, Growth of SMEs and the Nigerian Economy", International Journal of Business and Management, vol. 7, no. 13 , pp. 125 - 135, 2012. http://doi.org10.5539/ijbm. v7n13p125

[24] Tee, E., Boadi, L. A., \& Opoku, R. T., "The Effect of Tax Payment on the Performance of SMEs: The Case of Selected SMEs in Ghana West Municipal Assembly", European Journal of Business and Management, vol. 8, no. 20, 2016.

[25] Okolo, E. U., Okparaojiego, E. C., \& Okolo, C. V., "Effect of Multiple Taxation in Investment in Small and Medium Enterprises in Enugu State, Nigeria”, International Journal of Social, Behavioral, Educational, Economic, Business and Industrial Engineering, vol. 10, no. 1, 2016.

[26] Agot G. J., \& Ugwuoke, O. W., "Taxation and the Growth of Small and Medium Scale Enterprise (SMEs) in Nigeria: A Case of Selected SMEs in Nasarawa State", International Journal of Advanced Research in Accounting, Economics and Business Perspectives (IJARAEBP), vol. 2, no. 1, 2018.

[27] Cross, O. D., "Effect of Multiple Taxation on 
Small/Medium Enterprises in Nigeria”, International Journal of Advanced Research and Publications, vol. 3, no. 4, 2019.

[28] Pandey, P. \& Pandey, M. M., "Research methodology: tools and techniques", Romania: Bridge Center, 2015.

[29] Ghauri, P. \& Gronhaug, K., "Research Methods in Business Studies: A practical guide (3rd ed.)", Essex: Pearson
Education Limited, 2005.

[30] Osuji, U. S. A. \& Ishola, T. O., "Research Methodology (FMS 304)", Lagos: National Open University of Nigeria, 2012.

[31] Stuart, M. \& Nicola, H., "Research Methods Handbook: Introductory guide to research methods for social research", Manchester: Express Networks, n.d 